\title{
The Behavior of Government Bureaucracy in Public Services in Parigi Moutong Regency, Central Sulawesi Province, Indonesia
}

\author{
Suasa , Syamsul Bachri, Mustainah, Natsir Mangngasing
}

Department of Public Administration, Faculty of Social and Political Sciences. Tadulako University, City of Palu, Indonesia

DOI: $10.36348 /$ sjef.2020.v04i06.016 $\quad$ | Received: 17.06.2020 | Accepted: 24.06.2020 | Published: 26.06 .2020

*Corresponding author: Suasa

\section{Abstract}

This study aims to determine the behavior of government bureaucracy in public services. The study was conducted in Parigi Moutong District, with seven informants selected purposively also used a qualitative-descriptive research method. Data collection was carried out by interviews, observation, and literature review. Data analysis used seven bureaucratic behaviors with some aspects, namely caring, superior, transformative, professional, integrity, a vision of novelty, and agent of democratic governance. The results showed that the figure of the bureaucratic apparatus had not been realized if it was associated with public services. It is occurred due to the existence of the effect by the system of Nepotism and political intervention with several research findings. For example, a bureaucratic care attitude towards public services by paying attention to the level of education and competence, excellence, professionalism, integrity, and the vision of a person's novelty can not be used as the most important criteria. The important thing is that the person concerned has an emotional connection, i.e., as family or team successful at the time of the regional head election process. In addition, it also cannot be used as an agent of democratic governance because it places a person in a non-transparent way, there are still political interventions that lead to negative perceptions that the behavior of the bureaucratic apparatus does not adhere to moral-ethical values, such as, upholding the mandate, distancing themselves from conflicts of interest.

Keywords: Apparatus behavior, caring, superior, transformative, professional, integrity, public service.

Copyright @ 2020: This is an open-access article distributed under the terms of the Creative Commons Attribution license which permits unrestricted use, distribution, and reproduction in any medium for non-commercial use (NonCommercial, or CC-BY-NC) provided the original author and source are credited.

\section{INTRODUCTION}

Bureaucratic behavior is often seen in government agencies, which are also known as government bureaucracies. The term bureaucracy is given to government agencies because, at first, the ideal type of organization called bureaucracy is a form that accepted and applied by government agencies. The main task of the Government essentially provides services to the community in order to welfare improvement. Bureaucracy is a systematic, integrated, and comprehensive process or effort aimed at realizing good governance and bureaucracy is an instrument for the operation of an administration, where bureaucracy works based on the division of labor, a hierarchy of authority, an impersonality of relations, regulation of behavior, and technical ability in carrying out tasks and its function as the administration of Government [1].

Bureaucratic behavior is a form of concern that is expected by all parties, comprehensively that bureaucratic behavior is not a new phenomenon and its form is simple, but the tendency towards bureaucracy has undergone fundamental and significant changes has become one of the dominant institutions [2]. In fact, bureaucracy is one of the institutions that symbolizes the birth of the modern era, which needs to be understood and is always in contact with public services.

Various kinds of problems faced by the bureaucratic apparatus, as an effort to correct various weaknesses and anticipate environmental changes, then a new thought is needed to build a bureaucratic apparatus that is reliable, professional, and upholds the values of honesty and professional ethics in carrying out their duties and functions as organizers of development activities and organizers of public services.

The public administration perspective is known for a variety of pathologies that make bureaucratic behavior or officers unprofessional in carrying out their duties and functions so that the entire bureaucracy of the State government is able to face various challenges that may arise, whether political, economic, socio-cultural, and technological, various "diseases" that may have suffered or threatened to 
attack them need to be identified to then look for the most effective treatment therapies. Various bureaucratic pathologies are categorized into five groups, viz. [3]: (1) Pathology arising from the perceptions and managerial style of officials in the bureaucratic environment, (2) Pathology caused by lack knowledge and skills of the officers implementing various operational activities, (3) Pathology arising from the actions of members of the bureaucracy in violation of legal norms and applicable laws and regulations, (4) Pathology manifested in the behavior of bureaucrats that are dysfunctional or negative, (5) Pathology which is a result of the internal situation in various agencies within the government environment.

People's understanding of bureaucracy is very diverse, in simple terms, these opinions can be placed at two different poles. On the one hand, bureaucracy is seen as a form of organization that is effective, predictable, and able to provide services in a nonpartisan [4]. Bureaucratic behavior has a space between sofis behavior, which is a form of interaction between individuals and bureaucracy, in contact with the implementation of public service functions [5]. Behavioral aspects in organizations greatly determine the success of the bureaucracy in providing services by manifesting quality public services. This is if it is supported by the behavior of the bureaucracy as a public servant and the State is tasked with carrying out the function of the government bureaucracy as a civil servant. Subsequently intended to meet the needs of public services by community expectations.

The problem currently faced by the government bureaucracy is (1) a large government bureaucratic institution unfortunately supported by less professional apparatus resources; (2) The centralized work mechanism is still implemented in the performance of government bureaucracy; (3) Control over government bureaucracy is always carried out by the Government, for the Government, and from the Government; (4) Patron client in the government bureaucracy is an obstacle against the attempt to realize the red tape in the bureaucracy; (5) It is unclear and even tends to be no "sense of accountability" both institutionally and individually; (6) It is ambiguous and also tends to be no "sense of accountability" both institutionally and individually; (7) Understanding of apparatus resources is not adjusted to the needs and arrangement of bureaucratic institutions [6].

The services of a first-class high official (called pejabat tinggi Pratama, in Indonesian) and administrators in Parigi Moutong Regency are still ineffective due to low professionalism of regional civil servants employees in carrying out their main duties and functions, in which scientific competence and expertise become one of the benchmarks in the service of first-class high official and the administrator of echelon II and echelon III (called as Camat, in Indonesian).

In reality and rationality, official structural service in the local government bureaucracy is not yet fully implement civil servants - Law No. 5, 2014 and Government Regulation No. 11, 2017. This is due to the interference of political interests and public officials have an emotional relationship that is family and the team succeeded during the process of local elections which influenced the composition of positions in the bureaucratic structural alignment. This study focuses on discussing the behavior of government bureaucracy in public services in the Parigi Moutong Regency in the period $2013-2018$.

\section{METHOD}

This research was conducted using a descriptive qualitative approach and carried out in Parigi Moutong Regency, Central Sulawesi Province. The focus of the observation was on the characteristics of government bureaucratic behavior in public services, taking informants from Echelon II and Echelon III (Camat). The data collection techniques used were interviews, observation, and literature review. Analysis of the data in this study, viz. [7]: (1) Data reduction, selecting and sorting data from interviews and observations as needed for the sake of the completion of the study, after the cut; (2) Data presentation arranged systematically based on the type and pattern of the data; (3) drawing conclusions and verification more in-depth to conclude and verify the results of research.

\section{RESULTS AND DISCUSSION}

\section{The behavior of Bureaucratic Apparatus Seen from the Care Aspect}

The behavior of the bureaucratic apparatus in terms of caring is also done by increasing the sensitivity of serving in accordance with changes in the work environment. The apparatus in placing a person in a structural position or first-class high official leader, and the position of the administrator must be sensitive to the rules that have been determined, such as, paying attention to one's education level and years of service [8]. The Government cannot run effectively due to the unprofessional conduct of regional employees in carrying out their primary duties and functions, which constitutes scientific potential and expertise that is one of the benchmarks in placing bureaucrats in occupying positions.

In reality and rationality, public services on the placement of structural officials in the government bureaucracy have not been in accordance with the laws and regulations of the Civil Service (Peraturan Perundang - Undangan Kepegawaian Aparatur Sipil Negara) No. 5 of 2014 and bureaucratic policies so far, apparently not effectively implemented. This is because the intervention of the political interests of public officials is very strong in influencing the composition of 
positions in the structural ranks, the behavior of government bureaucracy.

Based on the results of interviews, between the opinions of informants against conflicting theories, the theory explains that to occupy a position should be in accordance with one's competence, but the reality showed the criteria is ignored or the bureaucratic apprehension of the requirements is ignored, so it seemed that there was collusion and corruption and Nepotism in the placement carried out in the Government of Parigi Moutong Regency. Concern to this sensitivity is a consideration that must be addressed by every apparatus in placing structural officials or first-class high officials, and the position of administrator in each agency or institution needs it.

Based on the foregoing, the bureaucratic behavior in the form of service care must be corrected and improved by the apparatus in placing a person in a structural position or first-class high leader, and the position of administrator is to show concern for the needs of each agency or body in Government, providing guarantees comfort the trust in the community, and committed to having a sense of concern for bureaucratic reform. This is important to realize bureaucratic reform to understand the application of government bureaucratic behavior in the form of care in the placement of structural officials or first-class high official leaders and administrator positions.

\section{The Behavior of Bureaucratic Apparatus Seen From the Superior Aspects}

The State Civil Apparatus has the role of planner, executor, and supervisor of the implementation of the general tasks of Government and national development through the implementation of professional policies and public services, free from political intervention, and free from corrupt practices, collusion, and Nepotism. As appreciation and to get a role model (role model), the Ministry of Administrative and Bureaucratic Reform held the civil servant's Award for the second time. This event is an effort of the Ministry of Administrative and Bureaucratic Reform to motivate the state civil servant to be able to improve qualifications, competencies, and performance continuously. This appreciation is given to a civil servant who has carried out their duties well, even exceeding the expectations of Indonesian organizations and society [9].

Based on the results of the interview, it was found that the Civil Servant is expected to have adequate competence so that it is given the motivation to have better performance in the interests of the State and nation and to have an advantage according to the reality the bureaucratic apparatus is demanded to be superior, to get better appreciation such as occupying one particular position. Interview results prove that the behavior of the bureaucratic apparatus in the placement and dismissal of and in positions of employees, is not following the applicable provisions of excellence is not the main criteria, but who feels they want to work together in carrying out tasks and carried out solely for political purposes, so impressed placement is Nepotism and finally state civil servant does not work effectively.

The Government has an early expectation that state civil servants recruited through basic competency tests may produce superior government employees. One important pillar needed to prepare a superior Human Resources (HR) called as state employees, organizing both central and regional Governments [10]. These expectations have not been realized due to the Government's concern in implementing the apparatus HR management policy, namely the merit system which has not been implemented properly. Overall it is an essential capital for the creation of satisfying public services, basically how we encourage the government employees quality whose output is increasing public services.

\section{The Behavior of Bureaucratic Apparatus Seen from the Transformative Aspect}

In this study, Transformative is limited to aspects of the leadership behavior of the bureaucratic apparatus in placing someone in the echelon II and III (Camat) positions. Bureaucratic leadership is defined as a process of influencing employees to complete a job and directing the organization to be more compact and conducive, by applying concepts, values, ethics, character, knowledge, and skills. Based on this understanding, a boss who only uses authority to complete certain tasks and goals can not be called a leader, but only a boss. Leaders can influence employees to achieve goals, while leaders are only able to give orders. Bureaucratic reform must be carried out by improving the entire system so that the performance of government institutions can be immediately improved [11].

Based on the results of interviews, it was found that the behavior of the bureaucratic apparatus at the civil servant's placement to a particular position still cause unrest for those individual civil servants. It is due to placement in structural positions or first-class high official leaders, and the position of administrator seemed to depend on the desires of policymakers. It means that placement still leads to Nepotism. Three things you need to do is (1) changing the mindset of civil servants, which mischaracterized as devotion to the ruler or the ruling political party, became a public servant; (2) changing the work patterns of the bureaucracy, which so far have been regarded as routine linear obligations to be more professional; (3) improving bureaucratic relations with the community, which have become closer.

The bureaucracy is not transformative because it does not pay attention to one's ability to place in 
certain positions that are important as desired, which means that bureaucratic reform has not gone well. When referring to the vision of the Government of the Republic of Indonesia (President Joko Widodo - Vice President Jusuf Kalla), namely "The realization of a sovereign, independent and personality based on cooperation." The vision is contained in Nawacita's political ideals, which include "creating the government not absent by building clean, effective, democratic and reliable governance." This is undoubtedly the development of work culture within the government agency environment directed at the vision and goals. This vision is also following the great Vision of Bureaucratic Reform, called "The Realization of World Class Government in 2019". Therefore, with the development of agents of change, it is hoped that changes may occur larger and faster so that the government bureaucracy can achieve the title of worldclass.

\section{The Behavior of Bureaucratic Apparatus Seen from the Professional Aspect}

In this study, Professional is related to the suitability of the level of education, including managerial skills as well as the ability to utilize technology and the value of one's attitude. The results of research on the construction of apparatus professionalism: Leadership support and welfare improvement explain that professional apparatus is constructed as positive energy in individual performance, but cannot be separated from a conducive professional environment, such as decent employee welfare, clarity of sanctions if employees make mistakes, and giving rewards and encouragement to employees with a good work ethic [12].

Based on interviews with informants, it is proven that generally, the placement of structural officials or first-class official high leaders, and the position of administrator in Parigi Moutong Regency, has not been considered professional. Based on the criteria put forward by experts, that professionalism is the flow that applies the profession as the basic principle of human action. Other opinions about professionalism are based on criteria: (1) Knowledge, (2) Competent application, (3) Social Responsibility, (4) Self-Control, (5) Community Sanction [13]. Professionalism is a reflection of the skills and expertise of the apparatus. It effectively can run if supported by the proper knowledge on the basis of educational background with the workload that is its responsibility and also as a reflection of the self-potential of the apparatus, both in terms of ability and behavioral aspects, including loyalty, innovation, productivity, and creativity.

\section{The Behavior of Bureaucratic Apparatus Seen from the Integrity Aspect}

Integrity was a concept related to consistency in actions, values, methods, measurements, principles, expectations, and various things that are produced. People with integrity means having an honest person and having a strong character. Integrity is the virtue that encourages individuals who have it to make the best participatory efforts to realize a good life together. Integrity is always associated with morals or morality. As a human being, integrity is a good character, whereas, in an institution/organization, integrity is an excellent organizational culture. Both in a human being and in an institution/organization, integrity increases motivation to direct the functioning of particularity for the common good that as many people as possible can share [14].

A person is said to "have integrity" if his actions are under the values, beliefs, and principles he holds. Simply put, the character of a person of integrity is marked by only words and actions, not by someone whose words cannot be held. A person who has integrity is not a human type with many faces and appearances that are adjusted to his personal motives and interests. Integrity becomes a key character for a leader. A leader who has integrity will get the trust (trust) of employees. Leaders with integrity are trusted because what they say becomes their actions [15].

Integrity both individuals and organizations are needed in the achievement of goals, arguing that a person without integrity is difficult to carry out activities because they do not get trust, especially if a person has the opportunity to occupy a position as a leader element [16]. Running leadership in the organization, integrity as a foundation, therefore instill in oneself that is associated with consistency and commitment.

Based on the opinion of the informant, it was found that the bureaucratic apparatus did not yet have good integrity, because it still caused internal conflicts within the organization. This is caused by not being committed to the rule that someone occupying a position should be following the competencies they have, not the will of their superiors or political intervention. It shows that there has not been a commitment to the existing rules so that it appears that mistrust of the Government is low, as a result of being made a leader in a particular institution, or the Camat is not in accordance with his competence. Actually, this could have been done if there were no more state employees who met administrative requirements.

\section{The Behavior of Bureaucratic Apparatus Seen from the Novelty Vision Aspect}

Of the many problems of public administration in Indonesia, bureaucratic issues are most often a hot topic that is never completely overcome. For example, human resource management in carrying out promotions and placement of employees to occupy strategic positions, including structural positions or first-class official high leaders, and administrator 
positions which faced serious responses from public to the bureaucratic apparatus in Parigi Moutong Regency. Thos, due to the placement, still impressed the system of Nepotism and political intervention. One of the desired bureaucratic figures is the State Civil Apparatus which has a vision of novelty. This new vision is important to serve as one of the characteristics in Indonesia, which so far has been a failure to reform itself in response to the very high social, economic and political dynamics. One of the social and political dynamics that seems to have received a response from the community is a civil servant placement in a certain position has not yet carried out the reforms, as desired in the assessment of the placement based on education and professionalism.

Based on an interview from one of the informants, it was revealed that the bureaucratic reform in Parigi Moutong Regency was not yet as expected due to the desired apparatus figure. It was because all expectations have not been carried out properly, such as not yet carrying out the vision of newness in managing the expected civil servants because they do not care about one's professionalism. So the behavior of the bureaucratic apparatus is still in the category of not yet doing bureaucratic reform, because indeed those who have the authority in managing development are not under their expertise, so the development budget plan is not following the Regional budget.

\section{The Behavior of Bureaucratic Apparatus Seen from the Agent Democratic Government Aspects}

The application of good governance principles in the implementation of regional autonomy is a prerequisite for the implementation of regional autonomy. Besides, the implementation of regional autonomy is also determined by the collaboration of the Government, private sector and civil society as the implementation of good governance by their respective roles. Every actor of good governance can carry out their respective roles determined by the professional agents of the guarantor of good governance [17]. The old pattern of governance, which tends to be undemocratic, has begun to be opposed and rejected by people who demand changes towards good governance, that is, a government that engages the community and no longer makes the community only as spectators or as victims of absolute and authoritarian governance. The old pattern of governance is no longer in accordance with the changing social fabric. Therefore, according to Sedarmayanti, this demand is a natural thing and should be responded by the Government by making changes directed at the realization of good governance [18].

Discourse on good governance in this sense into Indonesian as governance, the governance or management of the new Government appeared around 15 recent years, especially after the various international financing institutions require "good governance" in a variety of aid programs. By the theoretical and administrative practitioners of the State of Indonesia, the term "good governance" has been translated into the implementation of trustful government, good governance, good and responsible governance, and there is also a narrow definition of clean governance.

According to informants' opinions, proved that the level of transparency in the management of human resources in the placement of officers in strategic levels or structural positions has not functioned as an agent of democratic governance. It was due to still carrying out activities that do not provide information to all members about the system of apparatus placement in structural positions. Public openness is a form of transparency that has implications for the Government's ability to realize good governance. For example, the Government can provide information about the rules of the game as well as detailed forms of public service activities. At least as stated in the law that the development of the State Apparatus is carried out through bureaucratic reform to improve the professionalism of the State apparatus and to realize good governance, at the center and in the regions, to be able to support the success of development in other fields [19].

Professionalism improvement means increasing abilities through both formal and non-formal education. So, according to the authors that to place the apparatus in structural positions or first-class high official leaders, and the position of administrator should pay attention to the level of education because one of the criteria for a person's professionalism can be revealed from the level of education. One step in human resources management is the placement where expected to placed according to their competencies that are owned.

\section{CONCLUSIONS}

The behavior of the bureaucratic apparatus in public service has not yet been realized in Parigi Moutong Regency when viewed from the aspect of caring, superior, transformative, professional, integrity, a vision of novelty, and agents of democratic governance. Civil servant placement referred to the nepotism system and the existence of political intervention is proven by several phenomena revealed. For example, the bureaucratic care attitude towards public services by paying attention to the level of education and competence, excellence, professionalism, integrity, and a person's vision of novelty cannot be used as the most important criteria. The essential thing is that the person concerned has an emotional connection, namely, as a family or election success team. Then, aside from not being able to be used as an agent of democratic governance because it places a person in a non-transparent manner. There is still political intervention resulting in a negative perception that the behavior of the bureaucratic apparatus does not 
adhere to moral-ethical values, such as upholding the mandate, distancing themselves from conflicts of interest.

\section{REFFFERENCE}

1. World Health Organization. (2008). Initiative mondiale pour l'élimination de la cécité évitable: plan d'action 2006-2011.

2. Thoha, M. (2003). Birokrasi dan politik di Indonesia. Divisi Buku Perguruan Tinggi, RajaGrafindo Persada.

3. Hamirul, H.(2019). Patologi Birokrasi Dalam Sebuah Monograf. Jambi: Sekolah Tinggi Ilmu Administrasi Setih Setio.

4. Robbins, S. P., \& Judge, T. A. (2008). Perilaku organisasi (Organizational behavior). Jakarta: Salemba Empat.

5. Ndraha, T. (2005). Kybernologi: Sebuah Rekonstruksi Ilmu Pemerintahan. Jakarta: Rineka Cipta.

6. Thoha, M.(2005). Manajemen kepegawaian sipil di Indonesia, Ed. 1., cet. 1. Rawamangun, Jakarta: Prenada Media.

7. Saldaña, J. (2014). Thinking qualitatively: Methods of mind. Sage Publications.

8. Simpson, G., Weber, M., Henderson, A. M., \& Parsons, T.(1948). 'The Theory of Social and Economic Organization.', Philos. Rev, 57(5) 524.

9. Apriandhini, M., \& Wahyuni, P. M. Kebijakan program tax amnesty sebagai bentuk kepatuhan wajib pajak. Transformasi sosial menuju masyarakat informasi yang beretika dan demokratis.
10. Hartono, B. D.(2019). 'SDM aparatur sipil negara juga harus unggul', Antara News, Aug. 19, 2019. https://www.antaranews.com/berita/1018958/sdmaparatur-sipil-negara-juga-harus-unggul.

11. Anwaruddin, A. (2006). Pengembangan model kepemimpinan birokrasi di indonesia. Jurnal Ilmu Administrasi: Media Pengembangan Ilmu dan Praktek Administrasi, 3(2), 01.

12. Wardiyanto, B., \& Hendrati, D. W. B. (2015). Konstruksi profesionalisme aparat: Dukungan pimpinan dan perbaikan kesejahteraan. Masyarakat, Kebudayaan dan Politik, 28(3), 125-138.

13. Murdick, R. G., Claggett, J. R., Djamil, D., \& Ross, J. E. (1986). Sistem informasi untuk manajemen modern. Erlangga.

14. Gufroni, G. (2018). Integritas Moral dan Korelasinya dengan Perilaku Korupsi. Prosiding Seminar Nasional \& Call for Papers Hukum Transendental.

15. Rumsey, M. G. (Ed.). (2013). The Oxford handbook of leadership. Oxford University Press.

16. Downe, J., Cowell, R., \& Morgan, K. (2016). What determines ethical behavior in public organizations: Is it rules or leadership?. Public Administration Review, 76(6), 898-909.

17. Akadun.(2007). 'Good Governance', Sosiohumaniora, 9(1), 1 .

18. Sedarmayanti.(2003). Good governance (kepemerintahan yang baik) dalam rangka otonomi daerah. Bandung: Mandar Maju.

19. Menteri Hukum dan Ham RI.(2017). UndangUndang No.17 Tahun 2007 Tentang Rencana Pembangungan Jangka Panjang Nasional (RPJPN) Tahun 2005- 2025 . 